\title{
Landmark-based Morphometric and Meristic Variations of Endangered Mrigal Carp, Cirrhinus cirrhosus (Bloch 1795), from Wild and Hatchery Stocks
}

(Morfometri berasaskan Mercu Tanda dan Variasi Meristik Mrigal Kap, Cirrhinus cirrhosus

(Bloch 1795) Terancam daripada Stok Liar dan Penetasan)

\author{
Dhiman Gain, MahfuJ, M.S., HuQ, K.A., ISlam, S.S., Minar, M.H., \\ GOUTHAM-BHARATHI, M.P. \& SIMON KUMAR DAS*
}

\begin{abstract}
Wild stocks of endangered mrigal carp, Cirrhinus cirrhosus (Bloch 1795), continues to decline rapidly in the Indo-Ganges river basin. With an objective to evaluate its population status, landmark-based morphometric and meristic variations among three different stocks viz., hatchery (Jessore), baor (Gopalganj) and river (Faridpur) in Bangladesh were studied. Significant differences were observed in 10 of the 15 morphometric measurements viz., head length, standard length, fork length, length of base of spinous, pre-orbital length, eye length, post-orbital length, length of upper jaw, height of pelvic fin and barbel length, two of the 8 meristic counts viz., scales above the lateral line and pectoral fin rays and 10 of the 22 truss network measurements viz., 1 to 10, 2 to 3, 2 to 8, 2 to 9, 2 to 10, 3 to 4, 3 to 8, 4 to 5, 4 to 7 and 9 to 10 among the stocks. For morphometric and landmark measurements, the 1 st discriminant function (DF) accounted for $58.1 \%$ and the 2 nd DF accounted for $41.9 \%$ of the among-group variability. In discriminant space, the river stock was isolated from the other two stocks. On the other hand, baor and hatchery stocks formed a very compact cluster. A dendrogram based on the hierarchical cluster analysis using morphometric and truss distance data placed the hatchery and baor in one cluster and the river in another cluster and the distance between the river and hatchery populations was the highest. Morphological differences among stocks are expected, because of their geographical isolation and their origin from different ancestors. The baseline information derived from the present study would be useful for genetic studies and in the assessment of environmental impacts on $\mathrm{C}$. cirrhosus populations in Bangladesh.
\end{abstract}

Keywords: Bangladesh; discriminant function analyses; Mrigal; truss morphometry

\section{ABSTRAK}

Stok mrigal kap liar terancam, Cirrhinus cirrhosus (Bloch 1795) terus menyusut dengan pantas di lembangan sungai Indo-Ganges. Dengan objektif untuk menilai semula status populasi, morfometri berasaskan mercu tanda dan variasi meristik antara tiga stok berbeza seperti, penetasan (Jessore), baor (Gopalganj) dan Sungai (Faridpur) di Bangladesh telah dikaji. Perbezaan ketara diperhatikan dalam 10 daripada 15 pengukuran morfometri seperti panjang kepala, panjang piawai, panjang cabang, panjang pangkal tulang belakang, panjang pra-orbit panjang mata, panjang pasca orbit, panjang rahang atas, ketinggian fin pelvik dan panjang barbel, dua daripada 8 kiraan meristik seperti sisik di atas garis deria dan sinar sirip pektoral serta 10 daripada 22 pengukuran rangkaian kekuda antara stok iaitu 1 hingga 10, 2 hingga 3, 2 hingga 8, 2 hingga 9, 2 hingga 10, 3 hingga 4, 3 hingga 8, 4 hingga 5, 4 hingga 7 dan 9 hingga 10. Bagi pengukuran morfometri dan mercu tanda, fungsi diskriminasi (DF) pertama menyumbang sebanyak $58.1 \%$ dan DF kedua menyumbang $41.9 \%$ kebolehubahan antara kumpulan. Dalam ruangan diskriminasi, stok sungai dipencilkan daripada dua stok lain. Selain itu, stok baor dan stok penetasan membentuk kelompok yang sangat padat. Dendrogram yang berdasarkan analisis kelompok hierarki menggunakan morfometri dan data jarak kekuda meletakkan penetasan dan baor dalam satu kelompok dan sungai dalam kelompok yang lain serta jarak antara populasi sungai dan penetasan adalah yang tertinggi. Perbezaan morfologi antara stok telah dijangka disebabkan pengasingan geografi serta asal-usul mereka daripada nenek-moyang yang berbeza. Maklumat asas yang diperoleh daripada kajian ini adalah penting untuk kajian genetik dan penilaian kesan alam sekitar terhadap populasi C. cirrhosus di Bangladesh.

Kata kunci: Analisis fungsi diskriminasi; Bangladesh; kekuda morfometri; Mrigal

\section{INTRODUCTION}

Phenotypic plasticity in a species is the aggregation results of growth, ontogenic development and maturation (Cadrin 2000), which leads to the expression of genotypes that are greatly influenced by the genetic and environmental interactions (Thompson 1991). Species-specific phenotypic plasticity among fish populations is prejudiced by a combination of ecological factors and abiotic factors 
(Sara et al. 1999; Turan 2000) and this could be a useful tool in assessing the short-term, environmentally induced variations (Begg \& Waldman 1999; Tzeng 2004).

Variations in the morphometric and meristic characters have been used extensively for stock identification. Fish stock structures have been analyzed for Catla catla (Ujjainia \& Kohli 2011), Megalapsis cordyla (Sajina et al. 2011), Rastrelliger kanagurta (Jayasankar et al. 2004), Labeo bata (Nahar et al. 2013), Labeo calbasu (Hossain et al. 2010), Glossogobius gieuris (Mollah et al. 2012), Heteropneustes fossilis (Rahman et al. 2014) and Labeo gonius (Begum et al. 2013) in the Indian subcontinent.

The mrigal carp, Cirrhinus cirrhosus (Bloch 1795), is a freshwater fish species belonging to the Cyprinidae family, is an essential food fish in the Indian subcontinent and a principal species in polyculture systems (Biswas et al. 2006). It is a detritus feeder, inhabiting the bottom layer of the water body and is an important component for the specific ecological niches (Chauhan et al. 2007). This fish is considered as the top 20 freshwater cultured species with a production of 287,200 tonnes in the year 2007 (FAO 2009). Though this species is widely distributed, it is found in less than five locations and has been assessed as vulnerable (Rema Devi \& Ali 2011), with a large population decline, possibly of more than $80 \%$ based on catch data in the Indo-Ganges river basin (Payne et al. 2004; Rema Devi \& Ali 2011). The natural breeding ground of mrigal carp and other fish species is deteriorated due to incessant degradation of habitat caused by environmental alteration and artificial interventions affecting spawning and feeding migration (Das \& Barat 1990). Consequently, the size of the hatchery sources of mrigal carp populations has been reduced due to unwise breeding plans such as uncontrolled hybridization (Rahi \& Shah 2012), inbreeding, genetic drift and bottleneck effect (Das et al. 2014; Saha et al. 2010; Simonsen et al. 2004). In order to evaluate the population status of the fast-depleting mrigal carp resources, the present study has been carried out in evaluating the phenotypical variations from three different stocks using landmarkbased morphometric and meristic characters.

\section{MATERIALS AND METHODS}

\section{SAMPLING}

During September 2013 to February 2014, C. cirrhosus samples $(n=60)$ were purchased from three different stocks:

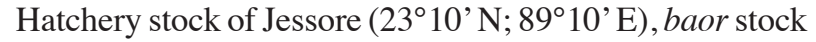
of Gopalganj $\left(23^{\circ} 19^{\prime} \mathrm{N} ; 88^{\circ} 70^{\prime} \mathrm{E}\right)$ and river stock of Faridpur $\left(23^{\circ} 21^{\prime} \mathrm{N} ; 8^{\circ} 47^{\prime} \mathrm{E}\right)$ (Figure 1 ). Hatchery stocks were purchased directly from the hatchery, baor stocks from the baor fishermen and river stocks from the farmers having river fry rearing business. The collected samples were placed individually into plastic bags and were kept in an ice box until transportation to the laboratory of Fish Biology under Fisheries and Marine Resource Technology Discipline, Khulna University, Khulna, Bangladesh.

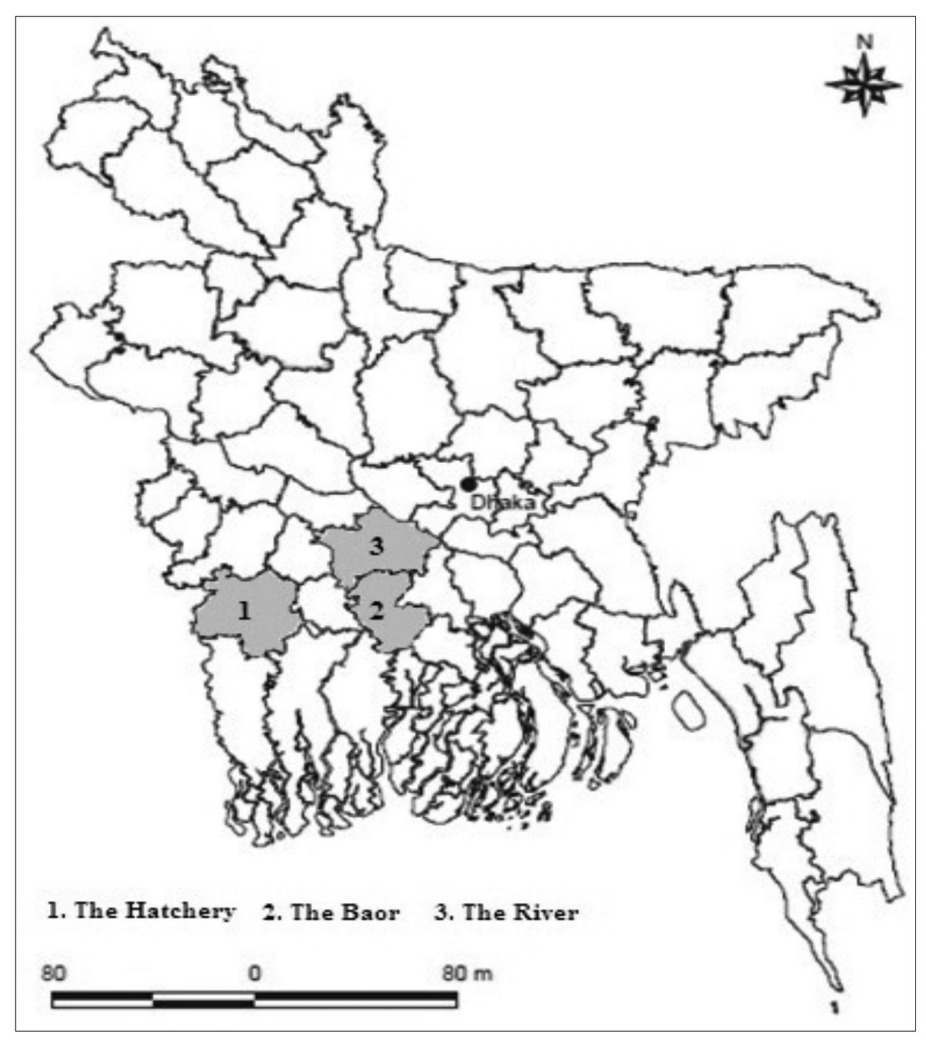

FIGURE 1. Map of Bangladesh showing the sampling sites of $C$. cirrhosus.

1. Hatchery of Jessore; 2. Baor of Gopalgunj and 3. River of Faridpur 


\section{MERISTIC AND MORPHOMETRIC COUNTS}

Eight meristic characters were counted which are given as follows: Number of scale on lateral line (NSoLL); number of scale above lateral line (NSaLL); number of scale below lateral line (NSbLL); fin rays in dorsal fin (FRDF); fin rays in caudal fin (FRCF); fin rays in anal fin (FRAF); fin rays in pectoral fin (FRPecF); fin rays in pelvic fin (FRPelF) and 15 morphometric characters (Table 1) were measured following the conventional method described by Hubbs and Lagler (1958). A magnifying glass was used to count the fin rays and only the principal rays were counted as a separate ray.

\section{LANDMARK-BASED MORPHOMETRIC MEASUREMENTS}

Twenty-two landmark-based morphometric measurements (Figure 2) were measured. Among 22 different distances were defined and measured on the body by placing the fish on a graph paper and landmark points were detected with a dissecting needle. Finally, the distances on the graph paper were measured by using Vernier callipers. Prior to analysis, it was necessary to eliminate any size effect from the data set. Variation should be attributable to body shape differences and not related to the relative size of the fish. In the present study, there were significant linear correlations among all measured characters and the total length of the fish. An allometric formula given by Elliott et al. (1995) was used to remove the size effect from the data set:

$$
\mathrm{M}_{\mathrm{adj}}=\mathrm{M}\left(\mathrm{L}_{\mathrm{s}} / \mathrm{L}_{\mathrm{o}}\right)^{\mathrm{b}},
$$

where $M$ is the original measurement; $M_{\text {adj }}$ is the sizeadjusted measurement; $\mathrm{L}_{\mathrm{o}}$ is the total length of fish; $\mathrm{L}_{\mathrm{s}}$ is the overall mean of standard length for all fish from all samples in each analysis. Parameter b was estimated for each character from the observed data as the slope of the regression of $\log \mathrm{M}$ on $\log \mathrm{L}_{\mathrm{o}}$, using all fish in all groups.

\section{STATISTICAL ANALYSES}

Meristic characters were compared using the nonparametric Kruskal-Wallis test. A univariate analysis of variance (ANOVA) was carried out to test the significance of morphological differences. In addition, all size-adjusted data were standardized and submitted to a discriminant function analysis (DFA). A dendrogram of the populations based on the morphometric and landmark distances data were drawn by the Squared Euclidean Dissimilarity

TABLE 1. Morphometric characters used for the analysis of mrigal carp C. cirrhosus stock variations

\begin{tabular}{|c|c|}
\hline Characters & Description \\
\hline Total length (TL) & Distance from the tip of the snout to the longest caudal fin ray \\
\hline Fork length (FL) & Distance from the tip of the snout to the middle part of the fork of the tail \\
\hline Standard length (SL) & Distance from the tip of the snout to the end of the vertebral column \\
\hline Trunk length (TrL) & the region of a fish between the head and anus \\
\hline Head length (HL) & Distance from the tip of the snout to the posterior margin of the opercula \\
\hline Snout length (SnL) & $\begin{array}{l}\text { Horizontal distance from the tip of the snout to the anterior margin of the pigmented } \\
\text { region of the eye }\end{array}$ \\
\hline Length of the upper jaw (LUJ) & Length of the maxilla \\
\hline Inter orbital (IO) & Distance between the orbits \\
\hline Pre orbital head length (PreOHL) & Distance from the tip of the snout to the anterior margin of the eye \\
\hline Eye length (EL) & Diameter of the eye \\
\hline Post orbital head length (POHL) & Distance from the posterior margin of the eye to the end of the operculum \\
\hline Pre-dorsal fin length (PrDL) & Distance from the snout tip to the anterior base of 1 st dorsal fin. \\
\hline $\begin{array}{l}\text { Length of base of the spinous or first dorsal } \\
\text { fin (LBS) }\end{array}$ & Length of base of first dorsal fin \\
\hline Body depth (BD) & Vertical distance from the anterior part of the 1 st dorsal fin and ventral part of the body \\
\hline Least depth of the caudal peduncle (LDCP) & Caudal peduncle length \\
\hline Height of the pelvic fin (HPF) & Pelvic fin height \\
\hline Length of the base of the anal fin (LBAF) & Length of the base of anal fin \\
\hline Barbel length (BrL) & Length of the maxillary barbel \\
\hline
\end{tabular}




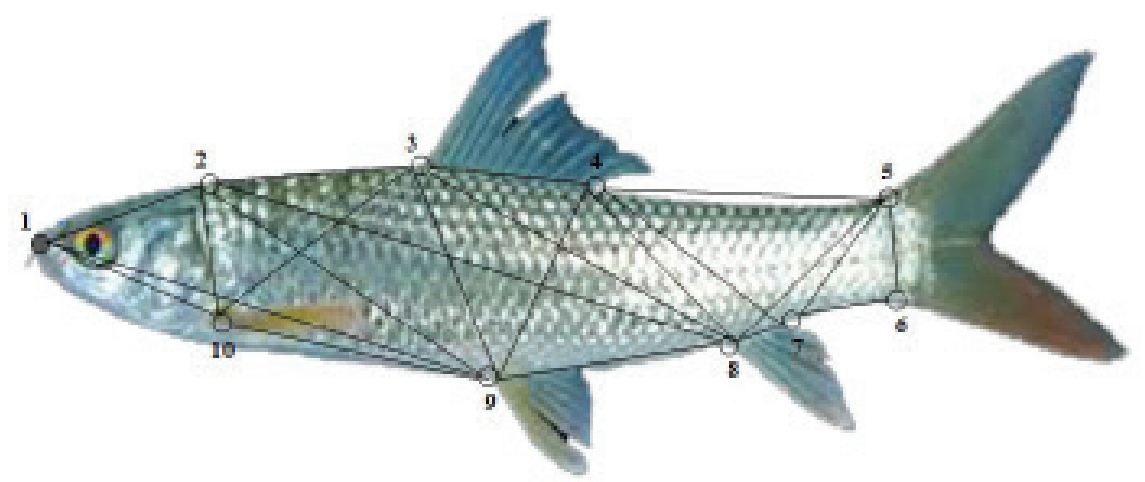

FIGURE 2. Location of the 10 landmarks for constructing the truss network on fish body illustrated as open circle and morphometric distance measures between the circles as lines. Landmarks refer to (1) anterior tip of snout at upper jaw, (2) most posterior aspect of neurocranium (beginning of scaled nape), (3) origin of dorsal fin, (4) insertion of dorsal fin, (5) anterior attachment of dorsal membrane from caudal fin, (6) anterior attachment of ventral membrane from caudal fin, (7) insertion of anal fin,

(8) origin of anal fin, (9) insertion of pelvic fin and (10) insertion of pectoral fin

TABLE 2. Univariate statistics (ANOVA) testing differences among samples from 15 morphometric and 22 truss measurements

\begin{tabular}{|c|c|c|c|}
\hline Characters & Wilks' Lambda & $\mathrm{F}$ & Significance \\
\hline HL & 0.18 & 97.96 & $0.000^{* * *}$ \\
\hline PrL & 0.98 & 0.44 & 0.642 \\
\hline SL & 0.18 & 95.10 & $0.000^{* * *}$ \\
\hline FL & 0.04 & 459.75 & $0.000^{* * *}$ \\
\hline LBS & 0.82 & 4.66 & $0.015^{*}$ \\
\hline $\mathrm{SnL}$ & 0.98 & .394 & 0.677 \\
\hline PrOL & 0.32 & 44.81 & $0.000^{* * * *}$ \\
\hline EL & 0.22 & 77.20 & $0.000^{* * *}$ \\
\hline POL & 0.83 & 4.36 & $0.019^{*}$ \\
\hline $\mathrm{BD}$ & 0.93 & 1.53 & 0.227 \\
\hline LDCP & 0.99 & 0.15 & 0.859 \\
\hline LBAF & 0.95 & 1.14 & 0.329 \\
\hline LUJ & 0.19 & 93.77 & $0.000^{* * *}$ \\
\hline HPF & 0.61 & 14.04 & $0.000^{* * *}$ \\
\hline $\mathrm{BrL}$ & 0.49 & 22.55 & $0.000^{* * *}$ \\
\hline 1 to 2 & 0.98 & 0.405 & 0.670 \\
\hline 1 to 9 & 0.99 & 0.230 & 0.796 \\
\hline 1 to 10 & 0.47 & 24.24 & $0.000^{* * *}$ \\
\hline 2 to 3 & 0.86 & 3.42 & $0.042^{*}$ \\
\hline 2 to 8 & 0.51 & 20.45 & $0.000^{* * *}$ \\
\hline 2 to 9 & 0.71 & 8.58 & $0.001^{* *}$ \\
\hline 2 to 10 & 0.41 & 31.46 & $0.000^{* * * *}$ \\
\hline 3 to 9 & 0.92 & 1.85 & 0.169 \\
\hline 3 to 10 & 0.90 & 2.34 & 0.107 \\
\hline 3 to 4 & 0.76 & 6.59 & $0.003^{* *}$ \\
\hline 3 to 8 & 0.73 & 8.04 & $0.001^{* *}$ \\
\hline 4 to 5 & 0.74 & 7.36 & $0.002^{* *}$ \\
\hline 4 to 7 & 0.78 & 6.15 & $0.004^{* *}$ \\
\hline 4 to 8 & 0.96 & 0.71 & 0.497 \\
\hline 4 to 9 & 0.99 & 0.11 & 0.891 \\
\hline 5 to 6 & 0.96 & 0.91 & 0.407 \\
\hline 5 to 7 & 0.94 & 1.32 & 0.276 \\
\hline 5 to 8 & 0.94 & 1.30 & 0.281 \\
\hline 6 to 7 & 0.98 & 0.31 & 0.732 \\
\hline 7 to 8 & 0.97 & 0.50 & 0.610 \\
\hline 8 to 9 & 0.89 & 2.49 & 0.094 \\
\hline 9 to 10 & 0.27 & 56.77 & $0.000^{* * *}$ \\
\hline
\end{tabular}

${ }^{*} p<0.05,{ }^{* *} p<0.01,{ }^{, * * *} p<0.001$. Characters are defined in Table 1 
Distance. All statistical analysis were done using SPSS version 22 (SPSS, Chicago, IL, USA).

\section{RESULTS}

Meristic counts for all samples ranged from 42-46 in (NSoLL), 14-15 for FRDF, 14-17 for FRPecF, 8-10 for FRPelF, 7-9 for FRAF, 20-24 for FRCF, 5-7 for NSaLL and 5-7 for NSbLL in the 3 stocks examined. Significant differences were observed from all the meristic characters examined except for NSaLL and FRPecF (Kruskal-Wallis test; $p>0.05, p>0.01$ and $p>0.001)$.

After the allometric transformation, the correlation results showed that all of the morphometric and landmark variables studied were free from the influence of size. Univariate statistics (ANOVA) shows that $10 \mathrm{HL}, \mathrm{SL}, \mathrm{FL}$, LBS, PrOL, EL, POL, LUJ, HPF, BrL among 15 morphometric characters and 10 ( 1 to 10,2 to 3,2 to 8,2 to 9,2 to 10,3 to 4,3 to 8,4 to 5,4 to 7 and 9 to 10 ) of 22 truss measurements significantly differed to varying degrees $(p<0.05, p<0.01$ and $p<0.001)$ among samples (Table 2). Prior to discriminant analyses (DA), discriminant function scores 1 and 2 were determined on the basis of software process using size adjusted general morphometric and landmark distances and plotted in the discriminant space. In discriminant space, the river population of Faridpur was separated from the other two stocks (Figure 2), suggestive of the morphologically fragmented river stocks $C$. cirrhosus. On the other hand, baor stocks of Gopalganj and hatchery stocks of Jessore showed a very close relationship. Discriminant function analyses produced two discriminant function (DF1 and DF2) for both morphometric and landmark measurements. For morphometric and landmark measurements, the $1 \mathrm{st}$ DF accounted for $58.1 \%$ and the $2 \mathrm{nd}$ DF accounted for $41.9 \%$ of among-group variability and together they explained $100 \%$ of the total among-group variability. Pooled within groups correlation between discriminant variables and DFs showed that among the 15 morphometric measurements, 4 measurements of FL, HPF, $\mathrm{BD}$ and LDCP dominantly contributed to the 1st DF while the remaining 11 (HL, LUJ, SL, EL, PrOL, BrL, LBS, POL, LBAF, PrDL and SnL contributed to the 2nd DF. Among the 22 truss measurements, 6 measurements ( 4 to 7,2 to 3,5 to 7, 5 to 6,4 to 8 and 1 to 9 dominantly contributed to the 1 st DF and the remaining 16 measurements contributed to the 2nd DF (Figure 3, Table 3).

A dendrogram based on the hierarchical cluster analysis using size adjusted general morphometric and landmark distance data for $C$. cirrhosus is shown in Figure 4. The dendrogram formed two main clusters; the isolated river stock in one cluster and the morphologically related baor and hatchery stocks.

\section{DISCUSSION}

The results of the current study showed a significant variability only in 2 of the 8 meristic counts examined. A similar difference in the meristic counts of Japanese charr, Salvelinus leucomaenis among the rivers and tributaries has previously been reported by Nakamura (2003). Variations in meristic counts have recently been reported in Labeo calbasu among the stocks of two isolated rivers, the Jamuna and Halda and a hatchery Hossain et al. (2010). Morphometric differences among stocks are expected, because of their geographical isolation and may have originated from different ancestors. Therefore, it is not unlikely that obvious environmental variations exist and this could be attributed the very small environmental changes from place to place in a small country like Bangladesh (Hossain et al. 2010). The truss network system can effectively be used to distinguish between the hatchery and wild stocks. In this case, more significant differences were expected because of the 2 completely different habitats i.e. one is an open-water habitat and the

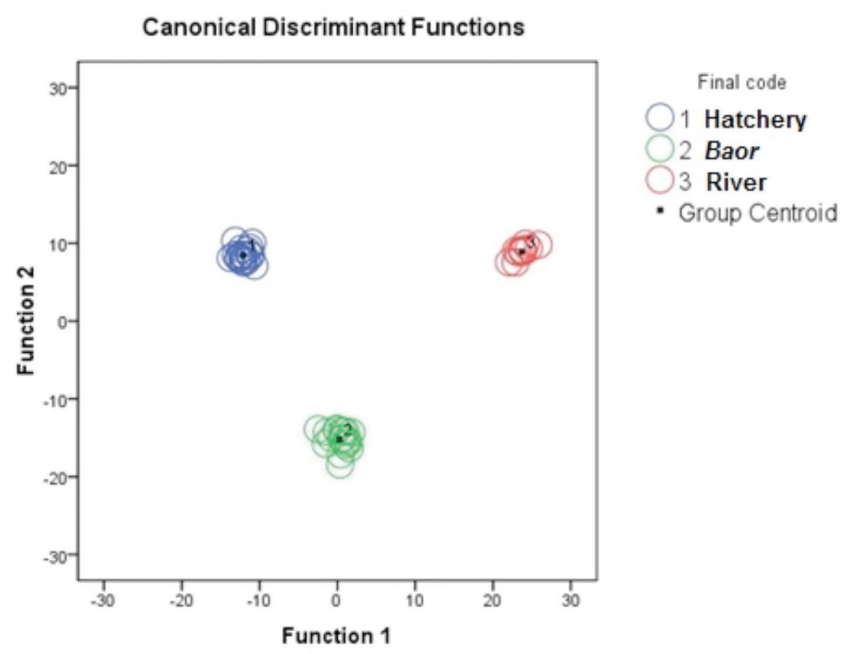

FIGURE 3. Sample centroids of the discriminant function scores based on morphometric and truss measurements 
TABLE 3. Pooled within-group correlations between discriminating variables and discriminant functions (DFs; variables ordered by size of correlation within function, ${ }^{*}$ denotes the largest correlation between each variable and DFs). For the definitions of characters, see Table 1

\begin{tabular}{lcc}
\hline Characters & DF1 & DF2 \\
\hline FL & $0.302^{*}$ & 0.151 \\
HPF & $-0.048^{*}$ & -0.037 \\
BD & $0.019^{*}$ & -0.003 \\
LDCP & $0.005^{*}$ & -0.003 \\
HL & 0.083 & $-0.149^{*}$ \\
LUJ & 0.090 & $-0.139^{*}$ \\
SL & 0.095 & $-0.135^{*}$ \\
EL & 0.074 & $-0.132^{*}$ \\
PrOL & 0.050 & $-0.105^{*}$ \\
BrL & 0.042 & $-0.070^{*}$ \\
LBS & -0.014 & $-0.035^{*}$ \\
POL & -0.016 & $0.033^{*}$ \\
LBAF & 0.010 & $-0.015^{*}$ \\
PrL & -0.004 & $0.011^{*}$ \\
SnL & 0.006 & $0.008^{*}$ \\
4 to 7 & $-0.038^{*}$ & -0.006 \\
2 to 3 & $-0.022^{*}$ & -0.021 \\
5 to 7 & $0.017^{*}$ & 0.006 \\
5 to 6 & $0.014^{*}$ & 0.005 \\
4 to 8 & $-0.011^{*}$ & 0.009 \\
1 to 9 & $-0.007^{*}$ & -0.003 \\
9 to 10 & 0.064 & $-0.113^{*}$ \\
2 to 10 & -0.053 & $0.080^{*}$ \\
2 to 8 & -0.025 & $-0.076^{*}$ \\
1 to 10 & -0.052 & $0.064^{*}$ \\
4 to 5 & -0.011 & $-0.047^{*}$ \\
2 to 9 & -0.030 & $-0.039^{*}$ \\
3 to 4 & 0.024 & $-0.036^{*}$ \\
3 to 8 & -0.033 & $-0.033^{*}$ \\
8 to 9 & 0.013 & $-0.024^{*}$ \\
3 to 10 & 0.014 & $-0.022^{*}$ \\
3 to 9 & -0.011 & $0.021^{*}$ \\
5 to 8 & $0.0086^{*}$ \\
7 to 8 & -0.007 & $0.010^{*}$ \\
6 to 7 to 9 & 0.005 & \\
\hline
\end{tabular}

other is closed water. Environmentally induced phenotypic variations; however, may have advantages in the stock structure analysis of exploited species, especially when the time is insufficient for significant genetic differentiation to accumulate among populations. Genetic markers might not be sufficient to detect existing genetic variation among populations and only a small proportion of DNA is analyzed by genetic markers.

Relationships among the 3 stocks differed according to whether the 1st or 2nd DF was considered (Figure 3). As the hatchery owners use brood fish collected from the river and baor, 2 major natural sources of mrigal in the country, the hatchery stocks showed some nearness to baor stocks. The 1st DF accounted for much more of the among group variability than did the $2 \mathrm{nd} D F$. It is obvious that the $2 \mathrm{nd}$ DF explains much less of the variance than does the 1st DF. The 2nd DF is; therefore, much less informative in explaining differences among the stocks. The dendrogram employed in this study resulted in 2 clusters: the baor and hatchery stocks in one and the river stock in another (Figure 4). The difference between the hatchery and wild stocks could be attributed to environmental as well as genetic variations.

\section{CONCLUSION}

There is an apparent decline from the wild sources of mrigal carp in the Indian sub-Continent. Landmark-based morphometric and meristic variations of mrigal carp collected from three different stocks showed significant differences in 10 of the 15 morphometric measurements, 2 of the 8 meristic counts and 10 of the 22 truss network 


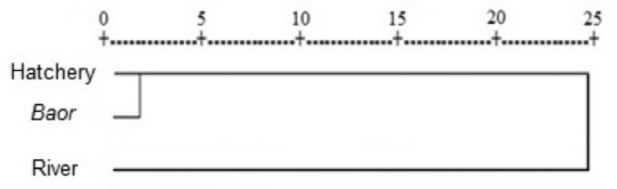

Distance of squared Euclidean dissimilarity

FIGURE 4. Dendrogram based on morphometric characters and landmark distances of the hatchery, Baor and river populations

measurements. Furthermore, the plotted DF too showed a significant morphological isolation among the stocks.

Consistent information and research of stock structure are crucial for balanced exploitation, selection and breeding, habitat restoration, management and conservation of species, subspecies, stocks and races. The baseline data derived from the present study would be useful for the conservation of the dwindling stocks of the mrigal carp and in designing breeding strategies. More research especially on genetic studies and investigations of the impacts of environmental factors is needed for conservation and mass seed production of selected stocks to pave the way to saving this endangered species from extinction.

\section{ACKNOWLEDGEMENTS}

The authors would like to thanks the laboratory assistants of Fisheries and Marine Resource Technology Discipline, Khulna University, Khulna, Bangladesh for their support throughout the study. We would also like to thank the anonymous reviewers for their comments that improved the quality of this paper. Thanks to UKM for the financial support through the research grant GUP-2015-025 to SKD.

\section{REFERENCES}

Begg, G.A. \& Waldman, J.R. 1999. An holistic approach to fish stock identification. Fisheries Research 43(1-3): 35-44.

Begum, A., Khan, M.M.R., Nahar, K., Minar, M.H., Sultana, N. \& Khan, M.G.Q. 2013. Morphological and genetic variations in wild and hatchery populations of gonia (Labeo gonius, Hamilton) using truss measurement and allozyme markers. International Journal of Life Sciences Biotechnology and Pharma Research 2(2): 204-221.

Biswas, G., Jena, J.K., Singh, S.K., Patmajhi, P. \& Muduli, H.K. 2006. Effect of feeding frequency on growth, survival and feed utilization in mrigal, Cirrhinus mrigala, and rohu, Labeo rohita, during nursery rearing. Aquaculture 254: 211-218.

Cadrin, S.X. 2000. Advances in morphometric identification of fishery stocks. Reviews in Fish Biology and Fisheries 10: 91-112.

Chauhan, T., Lal, K.K., Mohindra, V., Singh, R.K., Punia, P., Gopalakrishnan, A., Sharma, P.C. \& Lakra, W.S. 2007. Evaluating genetic differentiation in wild populations of the Indian major carp, Cirrhinus mrigala (Hamilton-Buchanan, 1882): Evidence from allozyme and microsatellite markers. Aquaculture 269: 135-149.

Das, P. \& Barat, A. 1990. Fish habitat degradation necessitating conservation. Environmental Series 4: 85-89.
Das, S.P., Bej, D., Swain, S., Mishra, C.K., Sahoo, L., Jena, J., Jayasankar, P. \& Das, P. 2014. Population divergence and structure of Cirrhinus mrigala from peninsular rivers of India, revealed by mitochondrial cytochrome $b$ gene and truss morphometric analysis. Mitochondrial DNA 25(2): 157-164.

Elliott, N.G., Haskard, K. \& Koslow, J.A. 1995. Morphometric analysis of orange roughy (Hoplostethus atlanticus) off the continental slope of southern Australia. Journal of Fish Biology 46: 202-220.

FAO. 2009. FishStat. Plus-universal software for fishery statistical time series. Version 2.3. Fisheries and Aquaculture Information and Statistics Service (FIES). Rome, Italy: FAO.

Hossain, M.A.R., Nahiduzzaman, M., Saha, D., Khanam, M.U.H \& Alam, M.S. 2010. Landmark-based morphometric and meristic variations of the endangered carp, Kalibaus Labeo calbasu, from stocks of two isolated rivers, the Jamuna and Halda, and a Hatchery. Zoological Studies 49(4): 556-563.

Hubbs, C.L. \& Lagler, K.E. 1958. Fishes of the great lakes region. Bulletin of Cranbrook Institute of Science 26: 1-213.

Jayasankar, P., Thomas, P.C., Paulton, M.P. \& Mathew, J. 2004. Morphometric and genetic analyzes of Indian mackerel (Rastrelliger kanagurta) from peninsular India. Asian Fisheries Science 17: 201-215.

Mollah, M.F.A., Yeasmine, S., Hossen, M.B . \& Ahammad, A.K.S 2012. Landmark-based morphometric and meristic variations of Glossogobius giuris in three stocks. Journal of Bangladesh Agricultural University 10(2): 375-384.

Nahar, K., Hossain, M., Begum, A., Sultana, N. \& Khan, M.G.Q. 2013. Genetic structure of endangered bata (Labeo bata, Hamilton) inferred from landmark-based morphometric and meristic measurements and allozyme markers. International Research Journal of Pharmaceutical and Applied Sciences 3(5): 145-160.

Nakamura, T. 2003. Meristic and morphometric variations in fluvial Japanese charr between river systems and among tributaries of a river system. Environmental Biology of Fishes 66: 133-141.

Payne, A.I., Sinha, R., Singh, H.R. \& Huq, S. 2004. A review of Ganges basin: Its fish and fisheries. In Proceedings of the Second International Symposium on the Management of Large Rivers for Fisheries, Sustaining Livelihoods and Biodiversity in the New Millennium, edited by Welcomme, R. \& Petr, T. RAP Publication 2004/16, vol. 1. Bangkok, Thailand: FAO Regional Office for Asia and The Pacific.

Rahi,L. \& Shah, S. 2012. Triploidization in rohu $\times$ mrigal hybrid and comparison of growth performance of triploid hybrid. Aquaculture Research 43: 1867-1879.

Rahman, M.M., Sharker, M.R., Sumi, K.R., Alam, M.A. \& Hossen, M.S. 2014. Landmark-based morphometric and meristic variations of stinging catfish, Heteropneustes fossilis (Bloch) among three isolated stocks, the Old Brahmaputra river and the Tanguar haor and a hatchery. International Journal of Fisheries and Aquatic Studies 1(3): 163-170.

Rema Devi, K.R. \& Ali, A. 2011. Cirrhinus cirrhosus. The IUCN Red List of Threatened Species 2011:e. T166531A6230103. http://dx.doi.org/10.2305/IUCN. UK.20111.RLTS.T166531A6230103.en. Accessed on 10 October 2016.

Saha, D., Nahiduzzaman, M., Akter, S., Islam, M.N., Hossain, M.A.R. \& Alam, M.S. 2010. Bottleneck in the endangered kalibaus, Labeo calbasu (cyprinidae: cypriniformes) populations in Bangladesh revealed by microsatellite DNA marker analysis. Genes and Genomics 32: 47-53. 
Sajina, A.M., Chakraborty, S.K., Jaiswar, A.K., Pazhayamadam, D.G. \& Sudheesan, D. 2011. Stock structure analysis of Megalaspis cordyla (Linnaeus, 1758) along the Indian coast based on truss network analysis. Fisheries Research 108: 100-105.

Sara, M., Favaloro, E. \& Mazzola, A. 1999. Comparative morphometrics of sharpsnout seabream (Diplodus puntazzo Cefti, 1777), reared in different conditions. Aquaculture Research 19: 195-209.

Simonsen, V., Hansen, M.M., Sarder, M.R.I. \& Alam, M.S. 2004. High level of hybridization in three species of Indian major carps. NAGA, WorldFish Center Quarterly 27(1 \& 2): 65-69.

Thompson, J.D. 1991. Phenotypic plasticity as a component of evolutionary change. Trends in Ecology \& Evolution 6: 246-249.

Turan, C. 2000. Otolith shape and meristic analysis of Herring (Clupea harengus) in the northeast Atlantic. Archive of Fishery and Marine Research 48(3): 283-295.

Tzeng, T.D. 2004. Stock identification of sword prawn Parapenaeopsis hardwickii in the East China Sea and Taiwan Strait inferred by morphometric variation. Fisheries Science 70: $758-764$

Ujjainia, N.C. \& Kohli, M.P.S. 2011. Landmark-based morphometric analysis for selected species of Indian major carp (Catla catla, Ham. 1822). International Journal of Food Agriculture and Veterinary Sciences 1: 64-74.

Dhiman Gain

Marine Environment and Resources Program

University of the Basque Country

Spain

Mahfuj, M.S.

Laboratory of Aquaculture and Artemia Reference Center Faculty of Bioscience and Engineering, Ghent University Belgium

Huq, K.A

Fisheries and Marine Resource Technology Discipline

Life Science School

Khulna University, Khulna 9208

Bangladesh

Islam, S.S .

Fisheries and Marine Resource Technology Discipline

Life Science School

Khulna University, Khulna 9208

Bangladesh
Islam, S.S.

Laboratory of Aquaculture and Artemia Reference Center Faculty of Bioscience and Engineering

Ghent University

Belgium

Minar, M.H.

Department of Fisheries (DoF)

Ministry of Livestock and Fisheries

Bangladesh

Goutham-Bharathi, M.P

Fisheries Science Division

ICAR-Central Island Agricultural Research Institute

Post Box No. 181, Garacharma (Post)

Port Blair - 744101

Andaman and Nicobar Islands

India

Simon Kumar Das*

Marine Science Programme

School of Environmental and Natural Resource Sciences

Faculty of Science and Technology

Universiti Kebangsaan Malaysia

43600 UKM Bangi, Selangor Darul Ehsan

Malaysia

Simon Kumar Das*

Marine Ecosystem Research Center

Faculty of Science and Technology

Universiti Kebangsaan Malaysia

43600 UKM Bangi, Selangor Darul Ehsan

Malaysia

*Corresponding author; email: skdas_maa@yahoo.com

Received: 28 December 2015

Accepted: 31 October 2016 